\title{
Epistemological and Semiotic Insight of Holophrastic Constructions
}

Irina Kovyneva ${ }^{a}$

Natalya Devdariania1

Natalya Petrova ${ }^{a}$

Anastasia Krasovskayaa

Kristina Itinson ${ }^{\mathrm{a}}$

${ }^{1}$ Natalya Devdariani, Karl Marx Street, 3, Kursk State Medical University, Kursk, 305041, Russia, E-mail: nata5375@rambler.ru a Karl Marx Street, 3, Kursk State Medical University, Kursk, 305041, Russia

Doi:10.5901/mjss.2015.v6n6s2p223

\section{Abstract}

This article analyzes holophrastic constructions $(\mathrm{HC})$ within a cognitive-oriented linguistic paradigm, which is based on flexible principles and strategies in the creation of new words. $\mathrm{HC}$ are updated in the process of communicative and cognitive human activity. The article presents the basic philosophical and linguistic concepts considering the way of forming and expressing thoughts with the help of compound neologisms - holophrases. These constructions demonstrate human intentions and emotions, as well as accumulated experience and knowledge. The complex of problems concerning the relation between the form and content of these linguistic units was analyzed. The attention is focused on form which could become a source of new senses and meanings. The authors consider the interaction of unilingualism and linguistic human experience in the creation of epistemological nature of holophrastic constructions. On the examples from English pragmatic potential of holophrastic constructions are characterized. Compound words find their specific detection in different languages.

Keywords: semiotic approach; correlation of form and content; grammatical and semantic categories of a language; holophrastic construction

\section{Introduction}

The boundaries of my language determine the boundaries of my world.

Ludwig Wittgenstein

The epithet from the Logical-Philosophical Treatise by Ludwig Wittgenstein has not only pragmatic but also philosophical meaning: the reality is mediated by the language that recreates it, making the image of the world which is unique for a certain language of a certain culture. In other words, the language contrasts with the reality.

The study of a language as a symbolic form of culture objectivation helps to plumb the mystery of human nature and the laws of his existence. As a rule, the researchers tend to show greater interest to various forms of language aspects in the periods of radical socio political changes. The break age of the firmly established system of philosophy and change in quite a stable conceptual reality creates a sort of a spiritual vacuum in society (Petrova N.E. 2014).

The need for filling up this vacuum determines the appearance of wide-scale need for leaving the reality for the illusionary ideal world. Various language systems, in many cases language forms serve as guides to this world.

Speech intention as the essential element of speech activity is externalized in language in the form of specific linguistic means. It is a complete system that links all the levels of a language.

\section{Objectives and Methodology}

The purpose of the research is to study from the point of view of the semiotic approach as the example of linguistic and cognitive structurization of the neologisms. The article is aimed at the comprehensive description of holophrase, or holophrastic constructions $(\mathrm{HC})$, not only as a means of word formation, but also as a system of world view. The research is based on the methodological statement that the objective reality is reflected in the language forms associated with both logical and aesthetic perception of the world. This idea requires comprehensive approach to the phenomenon concerned. Therefore, the abovementioned approach supposes studying the correlation of antithesis of form and content in linguistic 
philosophy.

To achieve the goal of the research the following methods were used: semiotic method of scientific inquiry, theoretically linguistic method, the method of continuous sampling, comparative method and the elements of cognitive analysis.

\section{Discussion of the Research Outcomes}

The range of problems of correlation of form and content - the two philosophic categories, traditionally used to characterize the means of organizing a thing and the material of the thing as such-varies greatly, setting various options of interpretation. Here are some of them:

Platon rendered form as a "prototype", the ideal of a thing that exists independently from material existence of the latter (Frejdenberg O.M., 1996);

- Aristotle understood matter (the content) as the basis and the possibility for things to exist or not. As to the form, he saw it as the inner aim of a thing that determines their unity (Aristotel', 2000);

- The notion of the form as the beginning introduced to the material world by means of mental effort, developed in classic German philosophy (G.W.F. Hegel, I. Kant, L.A. von Feuerbach, J.G. Fichte, F.W.J. von Schelling) (Kuznecov V.N. ,1983);

The orientation of Levi Strauss's structuralism on the study of "structures" (not on the study of form), because the opposition "content - form" is based on the indifference of the form to the content of the objects studied. "Form and content have the same nature and they are subject to one and the same analysis. The realness of the content is in its having a structure, while what is accepted to be called "form" is the product of "structuralization" of local structures which the content consists of" (Levi-Stross K., 1983).

The diversity of interpretations of antithesis "form - content" observed in philosophic conceptions takes place in linguistic investigations as well:

When interpreting the language content, a certain variety of language forms is neglected by logical grammar (Ishimoto A., 1993);

Empiristic Grammar has a tradition of deriving universal categories of linguistic thought directly from the language forms (D. Alighieri, A. Arnauld, C. Lancelot, M.V. Lomonosov, J. Wallis and others) (Susov I.P. ,1999);

- F.W. Humboldt's doctrine about the transformation of universal categories as forms of thought of logical nature in to certain grammatical categories Gumbol'dt V., 1985);

In the teaching of F. de Saussure, restoration of the semantic and formal plan of a language as the "signified" and the "signifier" in the simplest language sign. "Language is a sum of relations between the signified and the signifier" (Sossjur F. de., 2000);

- The signified and the signifier suppose one another. In the function of sign relation members each of them is impossible without this relation or beyond the connection with its correlate;

- The opposition of form and substance ("material") in glossematics of L. Hjelmslev. According to him, the material of plan of expression can be common for all languages, for example, it involves all sounds that a human being can pronounce. This common material serves as a screen for projecting the form of expression typical for the given language. It is the form of expression that forms the material of expression and turns it to the substance of expression. In a similar way, one and the same content material (extralinguistic situations as well as anything that can be the subject of thought) divides into parts and forms in a special way in every languages according to the form of content typical for this language. The form of each of the plans is a special structure (or a "scheme") unique for every particular language and is absolutely independent from the substance in which it is manifested (Zvegincev V.A., 1965);

- Studying the connection between the sounding and its semantic function in the works of A.A. Potebnya: "the number of sound meaningful combinations in a language is incomparably less than the number of images and meanings. In other words, the changeability and mobility of a thought in a language are much greater than the variety of sounds" (Potebnja A.A. ,1958);

- The idea of "deep" and "superficial" structures, developed in Chomsky grammar. Excluding semantics from syntax and presenting it in the form of "semantic interpretation" of abstract syntactic schemes, that occurs somewhere beyond the generative process, (Chomsky N., 1977). N. Chomsky closes the door to the further advance. However, some followers of generative grammar, who critically revalue the conception of $\mathrm{N}$. Chomsky, give more and more semantic content to the "deep structures notion". This semantic content to 
some extent becomes euphemism for the universal thought structures;

- The acceptance of multifunctionality of expression plane units and homophony of content plane units is taken as the basis of S. Kartsevskiy's conception about "asymmetric dualism of a linguistic sign" (Karcevskij S., 1965);

In the context of our research, the above-cited review of concepts is important for understanding the formality of the content and meaningfulness of the form. From this point using the notion "holophrastic construction" we mean it as one of the varieties of the form which can be seen from the point of view of symbolism, because "a word or an image are symbolistic if they imply something more than their obvious and direct meaning" (Devdariani N.V., 2012).

The dispute about form and content has a direct analogy with the matter of the relationship of language and thinking. This matter has been one of the central issues in theoretical linguistics, philosophy, psychology (psycholinguistics), sociology (sociolinguistics), semiotics, rhetoric, logic, study of art, cultural studies, pedagogics since the very beginning of their development.

Resolving this problem, wide differences are discovered: from direct identification of a language with thinking (J.G. Hamann, F.D.E. Schleiermacher) or their excessive connection with the exaggerated role of a language (K. Ajdukiewicz, P.W. Bridgman, L. Weisgreber, H. Glinz, W. von Humboldt, H.J. Ibsen, L. Levy-Bruhl, A. Tarski, J. Trier, J.D. Watson, P. Hartmann.) to complete denial of direct connection between them (F.E.Beneke) - the statement that thought consists of mental images only (J. Locke, B. Russel), or which is more common, disregarding of thinking in the methods of linguistic investigation (L. Bloomfield, L. Hjelmslev, G.L. Trager, F.F. Fortunatov, Ch.F. Hockett, Z. Harris).

The first standpoint stated that thinking can exist independently from the language (the content does not depend on the form) and that a language is merely a means of phrasing thoughts of a human. The utter form of this statement expressed in a famous aphorism that belongs to Arthur Shopenhauer, philosopher, who wrote that thoughts die the very moment when they turn to words.

The father of non-classic paradigm of interpretation of language phenomena and the founder of linguistic philosophy in the proper sense of the word is W. Humboldt. According to him, a language is not a formal means of expressing the results of our thoughts, but it is an "involuntary means" of the latter, that is, it is a procedural means of spiritual creativity and obtaining the truth. Thus, according to W. Humboldt, a language is a special world constituted by spirit, and it acts as a mediator between the spirit and the world of subjects: the mediation of subject notions by means of a language allows to make it the content of spirit, and this, in turn, gives the opportunity to think about the world (Gumbol'dt V. fon., 1984).

There is a wide range of phsychological conceptions formed on the basis of W. Humboldt's theory. They are:

- Comparative historical approach to a language as the organism that passes the stages of "formation" and "history of development" and the stage of "decomposition of language forms" caused by the deformation of the language by the spirit (A. Schleicher) (Desnickaja A.V., 1971);

- H. Steinhal's interpretation of a language as "an instinctive self-comprehension of the nation" (Shtejntal' G., 1964): "When we call the language an instinctive self-comprehension, instinctive worldview and logic, it means that the language is a self-comprehension, worldview and the logic of spirit of the nation";

The idea of a speech act as a purely psychological phenomenon in A. Potebnja's theory. The language brings in cultural and social principals to this act: "A thought by means of the word gets idealized and becomes free from ... the influence of direct sensorial perception ... A language is a condition of a nation's progress due to the same reason as it is the organ of thought of a particular person" (Potebnja A.A.,1989);

- Baudouin de Courtenay understood the subject of his research as "a real language that exists in its continuity only psychologically" (Bodujen de Kurtenje I.A., 1963);

The radicalism of neogrammarians (the representatives of Leipzig school: K. Brugmann, D. Delbruck, A. Leskien, H. Ostoff, H. Paul; Gottingen school: F. Behtel, A. Bezzenberger, A. Fick; Berlin school: J. Schmidt; Scandinavian school: S. Bugge, K. Verner) and their statement that the notions expressed by means of the language appear "in the depths of the heart" and "nowhere else", and that "the mental occurs in the individual's heart according to the general laws of individual psychology", and as a language is a psychological phenomenon, "any linguistic creativity is always individual" and therefore "there are as many unique languages as individuals in the world" (Paul' G.,1960);

- Postmodern vision of the language as a generative phenomenon that applies to the sphere of the unconscious, which usually escapes from the «jurisdiction» of verbal discourse. In the frame of the structural psychoanalysis there is a fixed linguistic form of "the existence of the unconscious as a speech of another person" (J. Lakan). As J. Lakan said, it's "desire" that "speaks" in the unconscious, and being articulated verbally, this desire loses its autochthony because it comes to be not only dependent, but practically specified 
by all applicable standards of grammatical system and rules of oral speech of the language. Thus, the vector of the "signified" as the objective forms of a language actually defines the individual destiny (Lacan J.,1977).

A different point of view rests on the fact that the influence of the language on the person is so strong that it defines his way of thinking, his cognitive activity. This approach to the language is represented by such branches in linguistics, as:

- neohumboldt tradition, according to which the external world enters the language only through the prism of a "national vision" (Weisgerber L., 1953);

- ethnolinguistic school (G. Pike, E. Sapir, B. Whorf) in the framework of which the conception of linguistic relativity was formed (Vasil'ev S.A.,1974);

French structural-formal school associated with the ideas of philosophical structuralism and hermeneutics and based on the thesis "A language is not a copy of reality". Language structures are interpreted first of all as a "tool" with the help of which people understand each other" (Martine A., 1960);

Sociolinguistics school (U. Leibov, W. Whitney, J. Fishman) focused on the problems of a language functioning in the sociocultural context (Labov W., 1972);

Modern conception of the interface "human-computer" (I. Vleimnik, R. Coates and others) that proves that it's the language that provides "the intellectuality of the system" (Kouts R., 1990);

Cognitive rational sphere that fosters focusing on linguistic totality: "cogitation and gnosis are predefined by world view through the language", and "all sorts of debates about language every time proved to be the language itself". "Language incarnates thought, gives to it a subsistent subtle embodiment. The element of a language is the element of play of thought, in which "the play plays upon the players" (Gadamer G., 2000);

- In this context philosophy constitutes as a special "speech activity" by definition of the statements that claim to be the absolute truth about the world in general. This is why "philology is a prehistory of human spirit" and just "in the language we usually feel at home to the same extent as we feel in the world" (H.-G. Gadamer) because "the world structure is similar to the structure of speech activity with such opportunities that no dictionary is able to provide" (Levinas Je.,1999);

Interpretation of a language as the expression of the activity of human essential existence. This interpretation was inspired by the late works of M. Heidegger: a language is the ability of a man "to say existence", and in this context a language is "a house of existence". "Gift of speech is a defining feature of a person that makes him a human being. This feature defines his existence... The very essence of the human being rests on the language" (Hajdegger M.,1999) , etc.

So, according to R.P. Trophimov (Trofimov R.P.,1975), "the language is not the process of reflection, but it is a process of forming and expressing the process of reflection which is cogitation". It is a part of a "complex unity, it is a social fact that supposes communication, at the same time it is an epistemological, psychological, and semiological fact that has logical conceptual and pragramtic approaches" (Leont'ev A.A.,1997).

Here we sum up the idea of a flexible connection between language and cogitation, their relativity and diversity with the words of a modern German grammarian W. Jung (Jung W., 1982): "By language we shall basically mean the constantly developing system of acoustically and optically perceivable signs. This system appeared in accordance with public needs, especially the needs of industrial activity and serves for forming thoughts, for thinking in the process of understanding the world and exchanging ideas and emotions, and gives the opportunity to fix and keep the gained knowledge". We accept this conceptual foundation as the basis for this research.

The deeper causes of the appearance of holophrase are the peculiarities of the modern way of thinking and the mentality. Derivations of this kind are quite common in modern fiction and are used to make the narration more lively; besides, they serve for better variability of linguistic means, puns, plays upon words, semantic compression, the generality of the utterance, etc.

A compound word (in our case it is $\mathrm{HC}$ ) as an intellectual mediator between the world of things which is located outside the person, and the world of ideas which is located in the person's consciousness gives him great opportunities of sharing "new" concepts, situations, properties, etc. of the objective world that have no direct names in the language. Therefore, the new personal meanings get their resuming nomination in holophrase. All the wealth of ideas reduces to one denotation. Just like in the experiment with magnifying glass or lens when we concentrate sun rays in one point and then out of this ray bundle we create an integral, the same we do when giving birth to a new thought. But in this case, holophrase plays the role of the focus. It can be a sign of a situation, event, process, such as for instance: "Jeannie mimicked a rose - petal - scattering motion" (Catherine Anderson "Always in My Heart"), "Since Mike's awakening, the two - people - at - time rule had been relaxes, along with the ten - minutes - per - hour rule." (Ann Packer "The Dive from Clausen's Pier").

Creative thought embraces the whole images of the outer world and converts them to special inner images with 
emotional layer: "And it was sweet to find herself the object of a teenage boy's crush - at - first - sight" (Nora Roberts "Villa").

Semiotic aspect of a language focused on linguistic abstraction, repeatedly became the object of theoretical analysis. A great number of scientific investigations and thesis researches are devoted to this issue. The integral semiotic approach was worked out by A. Wierzbicka, A.A. Vetrov, Y.M. Lotman, A.F. Losev, M.K. Petrov, Y.S. Stepanov.

Defining holophrastic constructions as semantically motivated hard detachable combinations of morphemes of a derivational and grammatical neologism, it is possible to study $\mathrm{HC}$, on the one hand, on the basis of internal principals of development peculiar to the language as a sign system, and, on the other hand - on the basis of human experience of image perception of the reality which expresses itself in the forms of linguistic coding appropriate for this perception -in this case, holophrastic constructions "Not - not He - Who - Must - Not - Be - Named, sir -" (J.K.Rowling "Harry Potter").Therefore, the authors of the research focused their attention on the problem of semiotic hybridization due to which occurs a sort of semantic compression of language content by way of crossing phonetic and visual linguistic images within one text unit (holophrastic construction) (Kovyneva I.A. ,2014).

To our opinion, holophrastic constructions don't only serve as a means of denoting the concepts needed for information-rich communication; they also denote the individual linguistic and imaginative worldview that stand behind these concepts. The authors of the article also think it necessary to point out that for the expression of such worldview a special linguistic form is needed which doesn't always find a set expression in the system of the language and in usage. E.g. "Hang on - this hasn't got anything to do with Vol- - sorry with You - Know - Who,has it?" (J.K.Rowling "Harry Potter"). For the adequate reflection of cognitive values in a language structure, the person needs to build verbal relationships and operations with "clear" form. When trying to overcome grammatical and semantic settings, the speaker seeks restoration of the original integrity and expression of his linguistic experience. From time to time the person tries to synthetically make up phrases which at first sight seem to have no common sense, but they actually keep the potential of visualization of expressing the creative and core aspects of the language, which, in the authors' opinion, remains an interesting linguistic task. E.g."...And right now - to be perfectly honest - you are letting it happen. You and Miss Meet You - Friday - Morning - Same - Time - as - Usual" (Karen Kingsbury "A Time to Dance")).

Every person's speech is unique and individual (both written and oral speech) because, as it is known, linguistic rules are flexible, and patterns or models create only the basis, the canvas for speech activity. More than that, the deviations from the speech patterns themselves become designed and reduce to patterns (e.g. " He felt useless, out of touch and more than a little panicked because his just-turned-seventeen-year-old son had driven off to school that morning behind the wheel of a secondhand convertible" (Nora Roberts "Villa")). (Kovyneva I., 2013).

When united in one text unit, they don't lose their applicability, and when singled out, they give a good idea of the mechanism of perception and the way the speaker analyses the situation: "I envisioned a romantic day filled with walks in the woods, quite dinners, a time to be together-alone-away from the watchful eyes of relatives and family friends." (Dorothy Greenbaum, M.D. "Lovestrong")

Though freedom of expression, including freedom of speech, presupposes the ability to give freedom to thoughts, the display of speech creativity is possible only within the boundaries set by the language system itself. In the process of creating holophrastic constructions takes place the display of freedom and dependence of speech creativity upon the language system. This process reveals the correlation between the stereotypic and creative principles of speech activity.

Most of the analyzed examples prove that the key role in the process of cognitive activity of a person belongs to visual perception. It is important to such an extent that the natural language, natural intelligence and human mentality can be called as "visually oriented" and "perceptive motivated": seeing is believing... (Rahilina E.V. 1999).

Indeed, "first, we see the world around us and only afterwards we start to perceive it with our minds" (Uryson E.V.,1996). Visual information is processed extensionally, integrally and entirely. Visual feelings "give to the person exceptionally rich and subtly differentiated data of wide range" (Rubinshtejn S.L., 1989): the person perceives the given object in all the "dimensions", manifestations and aspects at the same time: the shape of the object, its size, color, texture, weight, position, location, construction, background, other subjects associated with it, their connection, etc. The comprehensiveness of visual perception is expressed in non-segmented structure of holophrastic construction (e.g. "Toasab - built, black-paper-coveredhouse..." Robert Frost (The Poetry); "On his second album, singer - song writer Rhett Miller comes across as Ryan Adams with better hooks and better hair. "(People" magazine)).

Thus, visual expressiveness, in particular that of holophrastic constructions, in most books of the $20^{\text {th }}$ century caused complication of the meaning of the text as a semiotic system, not its simplification. At the beginning of the century ,the futuristic poets created an extensive catalogue of the possible ways of visual expressiveness. These linguistic phenomena appear to be clearly defined and actual at the syntax level of the graphics in a modern text. $\mathrm{HC}$ makes the issue of the boundary between words (part of the word) and sentences more actual. Here are the examples of a 
holophrastic sentence and even a holophrastic text: "Howcouldhehaveknown/wasfromMadison? Was there a never-lefthome look about me? A never-left-home, never-moved-from boyfriend-to-boyfriend, never-surprise-anyone look?" (Ann Packer "The Dive from Clausen's Pier"). Holophrastic formations in the structure of the text most commonly express the general meaning of the entire notion spelt in one word (e.g. "Hi this is Ann Smith Im looking for some one to watch my five year olds on he's no trouble really and we run avery relax edhouse hold" (Nicola Kraus \& Emma Mcloughlin "The Nanny Diaries")) (sometimes such spelling competes with the means of punctuation). With the help of holophrastic constructions it is possible to expressed the speed of text writing, like: "What? MissToo-Busy-to-Come follows Michigan football? By Karen Kingsbury "A Time to Dance", or to make the image brighter: "Beth was one of thoself-I- get- lonelyI'll -get-a-dogwomen..."(inthesameplace)

In some cases HC that represents a few words spelt as one, induces to read the text in a resegmented way. In texts with halves of the words, in particular in Robert Frost (The Poetry), for example, poetry, like this one:

\footnotetext{
"The house was full of tramping, and the dark,

Door-filling men burst in and dark,

A cannon-mouth-like hole was in the wall,

To which they set it true by eye:
}

The words presented in the text don't lose completely the morphological signs that point at the definite syntactical connection. It causes free combinability of language signs, which become analytical carrier of the meaning. Visual means of expression stylistically mark the elements of the text. It makes the marked and the unmarked elements stand in contrast to each other, or creates more complex structures of stylistic relationships between the parts of the text (e.g.) "He felt useless, out of touch and more than a little panicked because his just-turned-seventeen-year-old son had driven off to school that morning behind the wheel of a secondhand convertible" (Nora Roberts "Villa"). The given generalization of the ways of word formation - $\mathrm{HC}$ - shows that they are characterized by the highest level of semantic originality due to the absence of any linguistic limitations. In occasional stem composition the form of a linguistic unit itself becomes significant. Its flexibility gives birth to new fine stylistic nuances, emotional and pragmatic formations important for advanced reflections.

\section{Conclusion}

The analysis of usual as well as non-usual neologisms shows that the linguistic competence of the speaker includes his skills in forming new words not only according to the standards of common language word formation, but on the patterns of occasional and exotic word formation.

The study of the holophrastic constructions given in this article allows for the conclusion that this neologism can contain infinitely many semantic, emotional and pragmatic shades: "the infinite notional fullness of every linguistic element is the original specific of the language" (Losev A.F., 1981). That is why a language may be said to "hide great potentialities for expressing deep messages, the finest shades of feelings and emotions" (Orlov G.A., 1991). The dissonance between the world of thought and the world of words, the asymmetry of the deeper cognitive content and its verbal expression is one of the motive forces of development and supplementation of the language.

Thus, being a means of creating occasional words, holophrastic constructions, to all appearance, more than any other kind of linguistic creativity are based on using the principal cognitive abilities of a man, caused by his attempt to express the thought in its entirety. The formation of holophrastic constructions is connected with the intended violation of the borders between the words. As a rule, it is a well estimated step which allows to express the profundity of the thought without using any other means of expression. Grammatical and semantic categories of a language, in this case, don't only serve for the speaker's sharing the information, but control his mental activity by forming his thoughts.

Holophrastic constructions display the individual creative linguistic competence of the speaker and great creative capabilities of a language to create neologisms in the process of cognitive activity, and appear in different languages. The authors of the article see their future area of investigation in revealing the national cultural features of the mechanism of creating holophrastic constructions as well as in studying the issues connected with translation of the abovementioned language units from one language into another.

\section{References}

Aristotel'. Ritorika. Pojetika [AristotleRhetoric.Poetics].Moskva: 2000.

Bodujen de Kurtenje I.A. Izbrannyetrudypoobshhemujazykoznaniju [The chosen works on general linguistics].Moskva: Izdatel'stvo AN 
SSSR, 1963.

Chomsky N. Essays on Form and Interpretation. London, N.Y.: Longman, 1977.

Desnickaja A.V. O lingvisticheskoj teorii Avgusta Shlejhera [About the linguistic theory of August Schleicher].Moskva: 1971. p. 3-15.

Devdariani N.V. Filosofsko-kul'turologicheskie koncepty teorii K.G. Junga [The philosophical and culturological concepts of the theory of K.G. Jung]. / LAP LAMBERT Academic Publishing, 2012. p. 56.

Frejdenberg O.M. Antichnye teorii jazyka i stilja: Antologija tekstov [Antique theories of language and style: Anthology of texts]. SanktPeterburg: 1996.

Gadamer G.-G. Dialekticheskajaj etika Platona: Fenomenologija i interpretacija «Fileba» [Dialectic ethics of Platon: Phenomenology and interpretation of "Fileba"]. Moskva: 2000.

Gumbol'dt V. fon. Izbrannye trudy po jazykoznaniju [The chosen works on linguistics]. Moskva: Izdatel'stvo Progress, 1984.

Gumbol'dt V. Jazyk i filosofija kul'tury[The language and philosophy of culture]. Moskva: 1985.

Hajdegger M. Polozhenie ob osnovanii [Contributions to Philosophy].Sankt-Peterburg: 1999.

Ishimoto A. Logicheskaja grammatika: logiko-ontologicheskij obzor [Logical grammar: logical ontological overlook]. Moskva: 1993. p. $44-53$.

Jung W. Grammatik der deutschenSprache. Leipzig: Bibl. Institut, 1982.

Karcevskij S. Ob asimmetrichnom dualism elingvisticheskogo znaka[About asymmetric dualism of a linguistic sign]. Moskva: 1965. p. 85 $-90$.

Kouts R. Interfejs «Chelovek-komp'juter» [Human-computer interface]. Moskva: Izdatel'stvo Mir, 1990.

Kovyneva I. The idea of one way formation dictionary. Prague: CBU International Conference on Integration and Innovation in Science and Education, 2013.

Kovyneva I. A. Precedentnye teksty kak baza vozniknovenija golofrasticheskih konstrukcij [Precedent texts as a base of origin of holophrastic constructions].Kazan': 2014.

Kuznecov V.N. Nemeckaja klassicheskaja filosofija vtoroj poloviny XVIII - nachala XIX veka [The German classical philosophy of the second half of XVIII - the beginning of the XIX century]. Moskva: 1983.

Labov W. Sociolinguistic patterns. Philadelphia: Univ. of Pennsylvania Press, 1972.

Lacan 1977: Lacan J. Ecrits. A Selection. London: 1977.

Leont'ev A.A. Psihologija obshhenija [Communication psychology]. Moskva: Izdatel'stvoSmysl, 1997.

Levinas Je. Vremja i drugoj; Gumanizm drugogo cheloveka [Time and the other]. Sankt-Peterburg: 1999.

Levi-Stross K. Struktura i forma [Structure and forms]. Moskva: Izdatel'stvo Semiotika, 1983. p. 400 - 428.

Losev A.F. O ponjatii jazykovoj valentnosti [About concept of language valency]. Moskva: Izdatel'stvo Izvestija AN SSSR, 1981. p. 406 $-415$.

Martine A. Princip jekonomii v foneticheskih izmenenijah: (Problemy diahronicheskoj fonologii) [The principle of economy in phonetic changes: (Problems of diachronic phonology)]. Moskva: Izdatel'stvo Inostrannaja literatura, 1960.

Moskva: Izdatel'stvo Progress, 2000.

Orlov G.A. Sovremennaja anglijskaja rech' [Modern English speech]. Moskva: Izdatel'stvo Vysshaja shkola, 1991.

Paul' G. Principy istorii jazyka [The principles of the history of language]. Moskva: 1960.

Petrova N.E. Fonetiko-intencional'noe oformlenie nd inrechi: jazykovye sredstva i sposoby vyrazhenija jemocional'nogo soderzhanija [Phonetic atensional registration of the speech: language means and the ways of expression of an emotional content]. Kursk: 2014. p. 358-363.

Potebnja A.A. Iz zapisok po russkoj grammatike[From the notes of the Russian grammar]. Moskva: 1958.

Potebnja A.A. Slovo i mif [Word and myth]. Moskva: Izdatel'stvo Pravda, 1989.

Rahilina E.V. Kognitivny] analiz predmetnyh imen: ot sochetaemosti k semantike [Cognitive analysis of subject names: from compatibility to semantics]. Moskva: 1999.

Rubinshtejn S.L. Osnovy obshhej psihologii [Fundamentals of the general psychology].Moskva: Izdatel'stvo Pedagogika, 1989.

Shtejntal' G. Grammatika, logika i psihologija (ihprincipy i ihvzaimootnoshenija) [Grammar, logic and psychology (its principles and relations)].Moskva: 1964. p. $127-135$.

Sossjur F. de. Zametki po obshhejlingvistike [Écrits de linguistiquegénérale].

Susov I.P. Istorija jazykoznanija [The history of linguistics]. Moskva: Izdatel'stvo Tver', 1999.

Trofimov 1975: Trofimov R.P. Jengel's o vzaimosvjazi jazyka i soznanija [Engels about interrelation of language and consciousness]. Moskva: 1975. p. 133-139.

Uryson E.V. Sintaksicheskaja derivacija i «naivnaja» kartina mira [Syntactic derivation and "naive" picture of the world].Moskva: 1996. $p$. 25-28.

Vasil'ev S.A. Filosofskij analiz gipotezy lingvisticheskoj otnositel'nosti [Philosophical analysis of a hypothesis of linguistic relativity].Kiev: 1974.

Vitgenshtejn L. Logiko-filosofskiitraktat [TractatusLogico-Philosophicus].Moskva: Izdatel'stvoLogos, 1999.

Weisgerber 1953: Weisgerber L. Die inhaltbezogene Grammatik: (Von den Kräften der deutshenSprache).Düsseldorf: 1953. 367 S.

Zvegincev V.A. Istorija jazykoznanija XIX-XX vv. v ocherkah i izvlechenijah. [The history of linguistics of the XIX-XX centuries in sketches and abstracts].Moskva: 1965. p. 101-102. 